\title{
Pelaksanaan Pidana Pelatihan Kerja Terhadap Anak Pelaku Tindak Pidana
}

\author{
M. Alvi Rizki Ilahi, Elly Sudarty, Nys Arfa \\ Fakultas Hukum Universitas Jambi \\ Author's email correspondence: alvirizki1998@gmail.com
}

\begin{abstract}
ABSTRAK
Tujuan dari penelitian untuk mengetahui pelaksanaan pidana pelatihan kerja terhadap anak pelaku tindak pidana di Balai Rehabilitasi Sosial Anak Memerlukan Perlindungan Khusus Alyatama Jambi dan kendala yang dihadapi dalam proses pelaksanaan pidana pelatihan kerja tersebut. Dengan menggunakan metode yuridis empiris, penelitian menunjukkan bahwa: 1). Pelaksanan pidana pelatihan kerja di Balai Rehabilitasi Sosial Anak Memerlukan Perlindungan Khusus Alyatama Jambi dapat dikatakan belum terlaksana, Balai Rehabilitasi Sosial Anak Memerlukan Perlindungan Khusus Alyatama Jambi sebagai tempat pelaksanaan pelatihan kerja tersebut belum memberikan pelatihan kerja dikarenakan belum adanya Peraturan Pemerintah mengenai pelaksanaan pidana pelatihan kerja, sehingga Balai Rehabilitasi Sosial tersebut hanya memberikan Rehabilitasi berupa Terapi-terapi mulai dari terapi Psikososial hingga terapi mental dan spiritual 2). Kendala yang dihadapiyaitu dari Peraturan pelaksana yang belum ada, sarana dan prasaraan pendukung belum tersedia, serta belum adanya petugas yang secara khusus memberikan pelatihan kerja terhadap anak pelaku tindak pidana.
\end{abstract}

Kata Kunci: Pelaksanaan Pidana; Anak; Pelatihan Kerja.

\section{ARTICLE HISTORY}

Submission: 2020-06-09

Accepted: 2020-10-07

Publish: 2020-10-10

\section{KEYWORDS:}

Criminal Executiol; Children; Job Training.

\section{ABSTRACT}

The purpose of this research is to determine the implementation of job training crimes against children who are criminal offenders at the Child Social Rehabilitation Center in Need of Special Protection, Alyatama Jambi and the obstacles faced in the process of implementing the job training criminal. The research method used is empirical juridical legal research. The results of the study are: 1). It can be said that the implementation of job training crimes at the Child Social Rehabilitation Center Requires Special Protection Alyatama Jambi has not been implemented, the Child Social Rehabilitation Center Needs Special Protection Alyatama Jambi as a place for implementing job training has not provided job training because there is no Government Regulation regarding the implementation of job training penalties, so The Social Rehabilitation Center only provides Rehabilitation in the form of therapies ranging from psychosocial therapy to mental and spiritual therapy 2). The obstacles faced are from the missing implementing regulations, the supporting facilities and infrastructure are not yet available, and the absence of officers who specifically provide job training to child perpetrators of crime. 


\section{A. PENDAHULUAN}

Pemidanaan dapat diartikan sebagai tahap penetapan sanksi dan juga tahap pemberian sanksi dalam hukum pidana, pada dasarnya pidana dijatuhkan supaya seseorang yang telah terbukti berbuat kejahatan tidak lagi mengulanginya serta orang lain takut melakukan kejahatan serupa ${ }^{1}$. Tujuan sistem Peradilan pidana sesuai dengan UndangUndang Sistem Peradilan Pidana Anak adalah untuk menjaga harkat dan martabat anak, dimana anak berhak mendapatkan perlindungan khusus, terutama perlindungan hukum dalam sistem peradilan, oleh sebab itu sistem peradilan pidana anak tidak hanya ditekankan pada penjatuhan sanksi pidana bagi anak pelaku tindak pidana saja, melainkan juga difokuskan pada pemikiran bahwa penjatuhan sanksi dimaksudkan sebagai sarana mewujudkan kesejahteraan anak pelaku tindak pidana ${ }^{2}$.Di dalam proses penjatuhan pidana dan pemidanaan terdapat perbedaan antara orang dewasa dan anak-anak, terhadap orang dewasa antara lain tunduk sepenuhnya kepada KUHAP dan peraturan pelaksanaanya, sedangkan bagi anak diatur di dalam Undang-Undang Nomor 11 Tahun 2012 Tentang Sistem Peradilan Pidana Anak. Dalam Pasal 71 Ayat (1) Undang-Undang Nomor 11 Tahun 2012 Tentang Sistem Peradilan Pidana Anak, Pidana pokok bagi anak terdiri atas:
a) Pidana Peringatan
b) Pidana dengan syarat
1) Pembinaan di Luar Lembaga
2) Pelayanan Masyarakat
3) Pengawasan
c) Pelatihan Kerja
d) Pembinaan dalam Lembaga
e) Penjara

Berdasarkan beberapa pidana pokok yang dijatuhkan kepada anak, yang menjadi fokus utama saat ini adalah pidana pelatihan kerja yang sudah banyak di jatuhi putusan kepada anak pelaku tindak pidana di Pengadilan Negeri Jambi, hanya saja peraturan pemerintah dari Undang-Undang Nomor 11 Tahun 2012 mengenai Pelaksanaan Pidana Pelatihan Kerja hingga saat ini juga belum di terbitkan oleh pemerintah, hal ini menjadi suatu kendala bagi lembaga yang akan memberikan pelatihan kerja terhadap anak pelaku tindak pidana dikarenakan bentuk pelatihan kerja yang akan diberikan belum jelas di atur di dalam peraturan pemerintah. Berdasarkan data yang ada di Pengadilan Negeri Kelas I A Jambi, dari kurun waktu Mei - September 2018, setidaknya sudah ada 7 putusan perkara pidana yang pelakunya adalah anak yang dijatuhi pidana penjara dan pidana pelatihan kerja, khusus untuk pidana pelatihan kerja, berikut data putusan anak yang dijatuhi pidana pelatihan kerja di Pengadilan Negeri Jambi

\section{Tabel \\ Putusan Anak Pelaku Tindak Pidana yang dijatuhi Pidana Pelatihan Kerja di Pengadilan Negeri Kelas I A Jambi Tahun 2018}

Nandang Sambas, Peradilan Pidana Anak di Indonesia (Bandung: Graha Ilmu,2013), hlm. 9.

Lilik Mulyadi, Wajah Sistem Peradilan Pidana Anak Indonesia(Bandung: Alumni,2014), hlm. 6. 


\begin{tabular}{l|l|l|l|l} 
No & Periode & Nomor Putusan & $\begin{array}{l}\text { Lembaga } \\
\text { Pelatihan } \\
\text { Kerja }\end{array}$ & $\begin{array}{l}\text { Pidana } \\
\text { Pelatihan } \\
\text { Kerja }\end{array}$ \\
\hline 1 & Mei & 8/Pid.Sus-Anak/2018/PN.Jmb & $\begin{array}{l}\text { BRSAMPK } \\
\text { "Alyatama" }\end{array}$ & 3 Bulan \\
\hline 2 & September & 11/Pid.Sus.Anak/2018/PN.Jmb & $\begin{array}{l}\text { BRSAMPK } \\
\text { "Alyatama" }\end{array}$ & 3 Bulan \\
\hline 3 & September & 12/Pid.Sus.Anak/2018/PN.Jmb & $\begin{array}{l}\text { BRSAMPK } \\
\text { "Alyatama" }\end{array}$ & 3 Bulan \\
\hline 4 & September & $13 /$ Pid.Sus.Anak/2018/PN.Jmb & $\begin{array}{l}\text { BRSAMPK } \\
\text { "Alyatama" }\end{array}$ & 3 Bulan \\
\hline 5 & September & 14/Pid.Sus.Anak/2018/PN.Jmb & $\begin{array}{l}\text { BRSAMPK } \\
\text { "Alyatama" }\end{array}$ & 3 Bulan \\
\hline 6 & September & 15/Pid.Sus.Anak/2018/PN.Jmb & $\begin{array}{l}\text { BRSAMPK } \\
\text { "Alyatama" }\end{array}$ & 3 Bulan \\
\hline 7 & September & 16/Pid.Sus.Anak/2018/PN.Jmb & $\begin{array}{l}\text { BRSAMPK } \\
\text { "Alyatama" }\end{array}$ & 3 Bulan \\
\hline
\end{tabular}

Sumber: Pengadilan Negeri Kelas I A Jambi

Berdasarkan 7 putusan tersebut satu putusan yaitu putusan nomor 8/Pid.SusAnak/2018/PN.Jmb anak dijatuhi pidana pokok pelatihan kerja, sementara 6 putusan lagi dijatuhi pidana komulatif berupa pidana penjara dan denda, sementara pidana denda diganti pelatihan kerja, 7 orang anak ini ditempatkan di Balai Rehabilitasi Sosial Anak Memerlukan Perlindungan Khusus Alyatama Jambi.Balai Rehabilitasi Sosial Anak Memerlukan Perlindungan Khusus Alyatama Jambi dalam memberikan penanganan terhadap anak pelaku tindak pidana hanya berfokus kepada proses pemecahan masalah, berdasarkan Pasal 27 Peraturan Menteri Sosial Republik Indonesia Nomor 26 Tahun 2019 Tentang Rehabilitasi Sosial dan Reintegrasi Sosial Bagi Anak Yang Berhadapan Dengan Hukum dijelaskan Bahwa:

1. Pemecahan masalah atau intervensi sebagaimana dimaksud dalam Pasal 18 Ayat (1) huruf d merupakan pelaksanaan rencana pemecahan masalah atau intervensi bagi $\mathrm{ABH}$

2. Pemecahan masalah atau intervensi sebagaimana dimaksud pada ayat (1) meliputi:

a. Pemenuhan kebutuhan dasar

b. Terapi Psikososial

c. Terapi mental dan spiritual

d. Kegiatan pendidikan dan/atau pelatihan vokasional

Dari peraturan tersebut nampak jelas bahwa Balai Rehabilitasi Sosial Anak Memerlukan Perlindungan Khusus Alyatama Jambi tidak memberikan pelatihan kerja kepada anak pelaku tindak pidana, tetapi hakim Pengadilan Negeri Jambi memberikan putusan pidana pelatihan kerja dan menempatkan anak tersebut di Balai Rehabilitasi Sosial Anak Memerlukan Perlindungan Khusus Alyatama Jambi.

Pelaksanaan pidana pelatihan kerja terhadap anak pelaku tindak pidana inilah yang akan menjadi pusat analisis dalam penelitian ini dengan judul "Pelaksanaan 
Pidana Pelatihan Kerja Terhadap Anak Pelaku Tindak Pidana Di Wilayah Hukum Pengadilan Negeri Jambi"

\section{B. METODE PENELITIAN}

Tipe penelitian ini adalah yuridis empiris, penelitian ini bertujuan untuk memperoleh data tentang: 1). Pelaksanan pidana pelatihan kerja di Balai Rehabilitasi Sosial Anak Memerlukan Perlindungan Khusus Alyatama Jambi dapat dikatakan belum terlaksana, Balai Rehabilitasi Sosial Anak Memerlukan Perlindungan Khusus Alyatama Jambi sebagai tempat pelaksanaan pelatihan kerja tersebut belum memberikan pelatihan kerja dikarenakan belum adanya Peraturan Pemerintah mengenai pelaksanaan pidana pelatihan kerja, sehingga Balai Rehabilitasi Sosial tersebut hanya memberikan Rehabilitasi berupa Terapi-terapi mulai dari terapi Psikososial hingga terapi mental dan spiritual Kendala yang dihadapiyaitu dari Peraturan pelaksana yang belum ada, sarana dan prasaraan pendukung belum tersedia, serta belum adanya petugas yang secara khusus memberikan pelatihan kerja terhadap anak pelaku tindak pidana. 2). Kendala yang dihadapi yaitu dari Peraturan pelaksana yang belum ada, sarana dan prasaraan pendukung belum tersedia, serta belum adanya petugas yang secara khusus memberikan pelatihan kerja terhadap anak pelaku tindak pidana.

\section{PEMBAHASAN}

1. Pelaksanaan Pidana Pelatihan Kerja terhadap Anak pelaku tindak di Balai Rehabilitasi Sosial Anak Memerlukan Perlindungan Khusus Alyatama Jambi

Penerapan pidana pelatihan kerja terhadap anak pelaku tindak pidana, pada prinsipnya diharapkan dapat bermanfaat terhadap anak pelaku tindak pidana atau anak yang berkonflik dengan hukum. Melalui pelatihan kerja, anak yang berkonflik dengan hukum diharapkan dapat memiliki pengetahuan dan keterampilan bekerja sehingga ketika selesai menjalani masa pidananya, anak tersebut telah siap untk bekerja dalam kehidupan yang nyata, namun hal tersebut juga harus memeperhatikan hak-hak yang harus didapat anak mengingat anak adalah salah satu generasi penerus bangsa. Mengenai efektif atau tidak penjatuhan pidana pelatihan kerja tersebut, ada perbedaan pendapat antara hakim yang ada di Pengadilan Negeri Kelas I A Jambi, ada yang menyatakan penjatuhan pidana pelatihan kerja kepada anak itu sudah tepat, serta ada juga hakim yang menyatakan itu kurang tepat.

Hasil wawancara dengan Ibu Oktafiatri K. selaku salah satuhakim yang memutus pidana pelatihan kerja terhadap anak pelaku tindak pidana di Pengadilan Negeri Kelas I A Jambi menyebutkan bahwa pidana pelatihan kerja itu sebagaimana ditentukan dalam Pasal 71 Ayat (3) Undang-Undang Nomor 11 Tahun 2012 Tentang Sistem Peradilan Pidana Anak apabila hukumannya itu komulatif berupa penjara dan denda, maka pidana denda itu diganti dengan pelatihan kerja, karena rata-rata kasus anak yang di putuskan ini adalah tindak pidana yang hukumannya Komulatif, maka pidana pelatihan kerjalah yang efektif untuk di jatuhakan, karena memang pidana denda memang tidak efektif dijatuhkan kepada anak, oleh sebab itu diganti dengan pidana pelatiha kerja ${ }^{3}$.Berbeda dengan ibu Oktafiatri K yang beranggapan bahwa penerapan pidana pelatihan kerja terhadap anak sudah efektif, ibu Sinta

3 Wawancara dengan Ibu Oktafiatri K. Hakim Pengadilan Negeri Kelas I A Jambi, 7 Agustus 2019 
Gaberia Pasaribu selaku salah satu hakim di Pengadilan Negeri Kelas I Jambi kurang sependapat dengan hal ini, ia menjelaskan bahwa Dalam memutus penjatuhan pidana terhadap anak pelaku tindak pidana,terkhusus pidana pelatihan kerja tentunya hakim memiliki banyak sekali pertimbangan, walaupun undang-undang memang secara jelas sudah menyatakan bahwa salah satu pidana pokok terhadap anak adalah pidana pelatihan kerja, kemudian mengenai teknisnya pun sudah di atur, akan tetapi tidak adanya peraturan pemerintah mengenai pelaksanaan pidana pelatihan kerja membuat hakim memepertimbangkan untuk tidak menjatuhi pidana tersebut, karena dengan tidak adanya peraturan pemerintah, membuat bentuk dari pelaksanaan pidana pelatihan kerja tersebut tidak jelas, hal ini akan ditakutkan dapat menjadikan suatu bentuk perbudakan terhadap anak,mengingat seharunya anak memang belum tepat untuk menjalankan suatu pelatihan kerja ${ }^{4}$.

Mengenai lembaga yang dijadikan hakim Pengadilan Negeri Kelas I A Jambi untuk menepatkan anak pelaku tindak pidana, Balai Rehabiilitasi Sosial Anak Memerlukan Perlindungan Khusus Alyatama Jambi selalu dipilih Hakim sebagai tempat untuk anak pelaku tindak pidana menjalankan pidana pelatihan kerja, hanya saja jika dilihat dari Keputusan Menteri Sosial Republik Indonesia Nomor 85 Tahun 2017 Tentang Lembaga Penyelenggara Kesejahteraan Sosial, di mana di dalam lampiranya Balai Rehabilitasi Sosial Anak Memerlukan Perlindungan Khusus Alyatama Jambi juga terdapat didalamnya, tidak satupun dari tugasnya untuk memeberikan pelatihan kerja kepada anak pelaku tindak pidana, namun putusan Hakim Pengadilan Negeri Kelas I A Jambi menjatuhkan Putusan Pidana Pelatihan Kerja kepada anak pelaku tindak pidana, dan menempatkanya di Balai Rehabilitasi Sosial Anak Memerlukan Perlindungan Khusus Alyatama Jambi, hal ini menyebabkan kesulitan dalam hal menentukan bagi Balai Rehabilitasi Sosial Anak Memerlukan Perlindungan Khusus dalam hal jika ingin tetap harus memberikan pelatihan kerja.Berdasarkan tugas dari Balai Rehabilitasi Sosial Anak Memerlukan Perlindungan Khusus Alyatama Jambi, selaku salah satu penyelenggara Kesejahteraan Sosial Sebagai Pelaksana Rehabilitasi Sosial Anak Yang Berhadapan Dengan Hukum, tidak terdapat tugas untuk memberikan pelatihan kerja terhadap anak pelaku tindak pidana, Tetapi dalam putusan Hakim di Pengadilan Negeri Kelas I A Jambi menempatkananak pelaku tindak pidana untuk menjalankan pelatihan kerja di Balai Rehabilati Sosial Anak Memerlukan Perlindungan Khusus Alyatama Jambi.Berdasarkan Keputusan Menteri Sosial Republik Indonesia Nomor 26 Tahun 2018 Tentang Rehabilitasi Sosial Dan Reintegrasi Sosial Bagi Anak Yang Berhadapan Dengan Hukum, sejatinya hanya fokus kepada proses pemecahan masalah, yang pada Pasal 27 (2) peraturan menteri tersebut menjelaskan bahwa proses pemecahan masalah meliputi: 1) Pemenuhan kebutuhan dasar, 2) Terapi Psikososial, 3) Terapi mental dan spiritual, 4) Kegiatan Pendidikan dan/atau pelatihan vokasional. Terapi Psikososial merupakan pelayanan konseling individu maupun kelompok untuk pengembangan aspek kognitif, afektif, konatif, dan sosial yang bertujuan untuk terjadinya perubahan sikap dan perilaku ABH kearah yang adaptif.

4 Wawancara dengan ibu Sinta Gaberia Pasaribu, Hakim Pengadilan Negeri Kelas I A Jambi, 7 Agustus 2019. 
Sementara itu terapi mental dan spiritual merupakan kegiatan pemahaman pengetahuan dasar keagamaan, etika kepribadian, dan kedisiplinan yang ditunjukan untuk memperkuat sikap/karakter dan nilai spiritual yang dianut ABH. Dengan mempertimbangkan berbagai kekhususan seorang anak maka sudah seharusnya penanganan terhadap pelaku tindak pidana anak haruslah dilakukan secara khusus dengan lebih mengedepankan kepentingan anak 5 . Selain terapi Psikososial, terapi mental dan spiritual, sebenarnya, terdapat juga kegiatan pendidikan dan/atau pelatihan vokasional yang merupakan bentuk pelatihan penyaluran minat serta bakat dalm bentuk keterampilan kerja atau magang kerja kepada $\mathrm{ABH}$.

Balai Rehabilitasi Sosial Anak Memerlukan Perlindungan Khusus Alyatama Jambi belum memberikan pelatihan vokasional, dikarenakan belum ada fasilitas penunjang maupun petugas yang dapat memberikan pelatihan tersebut.maka dari itu hingga saat ini Balai rehabilitasi Sosial Anak Memerlukan Perlindungan Khusus Alyatama Jambi hanya memberikan pemenuhan kebutuhan dasar seperti pengasuhan, serta kebutuhan sandang, pangan, papan, serta hal lain yang paling ditekankan adalah pemberian terapi-terapu terhadap anak pelaku tindak pidana, hal ini bertujuan untuk memberikan pemulihan psikis dari anak pelaku tindak pidana yang telah banyak menerima tekanan baik dari dalam dirinya sendiri maupun dari lingkungannya.Hal ini disampaikan oleh Nurhasanah Seprianita selaku Kasi Layanan Rehabilitasi Sosial Anak Memerlukan Perlindungan Khusus Alyatama Jambi ia menjelaskan berdasarkan peraturan Menteri Sosial Republik Indonesia Nomor 26 Tahun 2018 tentang Rehabilitasi Sosial dan Reintegrasi Sosial Bagi Anak Yang Berhadapan Dengan Hukum, , bahwa setiap lembaga rehabilitasi anak, termasuk Balai Rehabilitasi Sosial Anak Memerlukan Perlindungan Khusus Alyatama jambi, di balai ini kami hanya memberikan beberapa tindakan seperti terapi psikosial yaitu memberikan pemulihan terhadap prilaku anak yang dianggap kurang baik, seperti melakukan pendekatan terhadap anak tersebut serta pelatihan untuk membentuk karakter, kemudian terapi mental, yaitu dengan memberikan pemulihan terhadap mental anak yang cukup tertekan dengan kondisi yang ia alami, dan terapi spiritual, dengan memberikan pencerahan rohani kepada anak pelaku tindak pidana yang di berikan oleh pemuka agama, sedangkan untuk pelatihan vokasional di balai ini secara tetap belum ada ${ }^{6}$.Balai Rehabilitasi Sosial Anak Memerlukan Perlindungan Khusus Alyatama Jambi, kedepannya juga ingin memberikan pelatihan vokasional tersebut jika sudah ada aturan yang jelas menenai bagaimana bentuk pelatihan yang akan diberikan serta sarana dan prasarana fasilitas penunjang pelatihan tersebut telah disediakan dan terdapat petugas - petugas khusus yang akan memberikan pelatihan tersebut. Dalam hal pemberian rehabilitasi terhadap anak pelaku tindak pidana, rehabilitasi ini diberikana mulai dari anak itu bangun tidur hingga tidur kembali, jadwal kegiatanyanya adalah sebagai berikut:

5 Hafrida, Yulia Monita, Elizabeth Siregar, "Pembinaan Narapidana Anak Di Lembaga Pemasyarakatan Anak Sel Bulu Muaro Bulian”, Publikasi Pendidikan, 5, 3 (2015), hlm. 200.

6 Wawancara dengan Nurhasana Seprianita, Kasi Layanan Rehabilitasi Sosial Anak Memerlukan Perlindungan Khusus Alyatama Jambi, Tanggal 21 Agustus 2019. 
Tabel

Jadwal Kegiatan Harian Di Balai Rehabilitasi Sosial Anak Memerlukan Perlindungan Khusus Alyatama Jambi

\begin{tabular}{c|c|c}
\multicolumn{1}{c}{ JAM } & KEGIATAN & PETUGAS \\
\hline $04.30-05.00$ & Bangun pagi dan Sholat & Petugas piket \\
\hline $05.00-07.00$ & Bersih diri \& lingkungan & Petugas piket \\
\hline $07.00-07.30$ & Sarapan pagi & Petugas piket \\
\hline $08.00-09.30$ & Morning Meeting & Seluruh Peksos \\
\hline $09.30-10.30$ & Terapi Psikososial & Peksos Pendamping \\
\hline $10.30-12.00$ & Terapi Sosial Kelompok & Peksos piket \\
\hline $12.00-14.00$ & Istirahat, sholat, makan & Peksos piket \\
\hline $14.00-15.30$ & Tidur siang & Peksos piket \\
\hline $15.30-16.00$ & Sholat Ashar & Petugas piket \\
\hline $16.00-17.00$ & Bercocok tanam & Peksos Piket \\
\hline $17.00-18.00$ & Bersih diri & Peksos piket \\
\hline $18.00-19.30$ & Sholat & Peksos piket \\
\hline $19.30-20.00$ & Makan malam & Petugas piket \\
\hline $20.00-04.30$ & Istirahat & Pengasuh
\end{tabular}

\begin{tabular}{c|c|c}
\hline \multicolumn{3}{c}{ SELASA } \\
\hline JAM & KEGIATAN & PETUGAS \\
\hline $04.30-05.00$ & Bangun pagi dan Sholat & Petugas piket \\
\hline $07.00-07.00$ & Bersih diri \& lingkungan & Petugas piket \\
\hline $08.00-07.30$ & Sarapan pagi & Petugas piket \\
\hline $09.30-10.30$ & $\begin{array}{c}\text { Apel,Sharing Feeling \& } \\
\text { Bimbingan Sosial }\end{array}$ & $\begin{array}{c}\text { Peksos Piket \& Peksos } \\
\text { Pendamping }\end{array}$ \\
\hline $10.30-12.00$ & $\begin{array}{c}\text { Pemeriksaan kesehatan } \\
\text { dan Terapi kesehatan }\end{array}$ & Perawat \\
\hline $12.00-14.00$ & Penyuluhan Sosial & Penyuluh \\
\hline $14.00-15.30$ & Istirahat, sholat, makan & Peksos piket \\
\hline $15.30-16.00$ & Tidur siang & Peksos piket \\
\hline $16.00-17.00$ & Sholat Ashar & Petugas piket \\
\hline $17.00-18.00$ & Terapi Mental Spiritual & Ustadz \\
\hline $18.00-19.30$ & Bersih diri & Peksos piket \\
\hline $19.30-20.00$ & Sholat & Peksos piket \\
\hline $20.00-04.30$ & Makan malam & Petugas piket \\
\hline & Istirahat & Pengasuh \\
\hline
\end{tabular}


RABU

\begin{tabular}{c|c|c}
\hline JAM & KEGIATAN & PETUGAS \\
\hline $04.30-05.00$ & Bangun pagi dan Sholat & Petugas piket \\
\hline $05.00-07.00$ & Bersih diri \& lingkungan & Petugas piket \\
\hline $07.00-07.30$ & Sarapan pagi & Petugas piket \\
\hline $08.00-08.30$ & Apel & Peksos piket \\
\hline $08.30-09.30$ & Terapi Sosial Kelompok & Peksos piket \\
\hline $10.30-12.00$ & Materi Kesejahteraan & Pejabat Struktural \\
& Sosial dan Masyarakat & \\
\hline $12.00-14.00$ & Istirahat, sholat, makan & Peksos piket \\
\hline $14.00-15.30$ & Tidur siang & Peksos piket \\
\hline $15.30-16.00$ & Sholat Ashar & Petugas piket \\
\hline $16.00-17.00$ & Olahraga & Peksos piket \\
\hline $17.00-18.00$ & Bersih diri & Peksos piket \\
\hline $18.00-19.30$ & Sholat & Peksos piket \\
\hline $19.30-20.00$ & Makan malam & Petugas piket \\
\hline $20.00-04.30$ & Istirahat & Pengasuh
\end{tabular}

KAMIS

\begin{tabular}{c|c|c}
\hline JAM & KEGIATAN & PETUGAS \\
\hline $04.30-05.00$ & Bangun pagi dan Sholat & Petugas piket \\
\hline $05.00-07.00$ & Bersih diri \& lingkungan & Petugas piket \\
\hline $07.00-07.30$ & Sarapan pagi & Petugas piket \\
\hline $08.00-09.30$ & Mrning Meeting & Peksos piket \\
\hline $09.30-12.00$ & Penyuluhan Sosial \& & Perawat \& Penyuluh \\
& Penyuluhan Kesehatan & Sosial \\
\hline $12.00-14.00$ & Istirahat, sholat, makan & Peksos piket \\
\hline $14.00-15.30$ & Tidur siang & Peksos piket \\
$15.30-16.00$ & Sholat Ashar & Petugas piket \\
\hline $16.00-17.00$ & Terapi Mental Spiritual & Ustadz \\
\hline $17.00-18.00$ & Bersih diri & Peksos piket \\
\hline $18.00-19.30$ & Sholat & Peksos piket \\
\hline $19.30-20.00$ & Makan malam & Petugas piket \\
\hline $20.00-04.30$ & Istirahat & Pengasuh
\end{tabular}

JUMAT

\begin{tabular}{c|c|c}
\hline JAM & KEGIATAN & PETUGAS \\
\hline $04.30-05.00$ & Bangun pagi dan Sholat & Petugas piket \\
\hline $05.00-07.00$ & Bersih diri \& lingkungan & Petugas piket \\
\hline $07.00-07.30$ & Sarapan pagi & Petugas piket \\
\hline $08.00-09.30$ & Apel & Peksos Piket \\
\hline $08.00-10.00$ & Olahraga/Senam & Peksos piket \\
\hline
\end{tabular}


PAMPAS: Journal of Criminal Law Vol. 1, No. 2

\begin{tabular}{c|c|c}
\hline $10.00-11.00$ & Gotong Royong & Peksos piket \& Pengasuh \\
\hline $11.00-12.00$ & Persiapan Sholat Jumat & Peksos piket \\
\hline $12.00-15.30$ & $\begin{array}{c}\text { Sholat Jumat \& Makan } \\
\text { siang }\end{array}$ & Peksos piket \\
\hline $15.30-16.00$ & Sholat Ashar & Petugas piket \\
\hline $16.00-17.30$ & Olahraga & Peksos piket \\
\hline $17.30-18.00$ & Bersih diri & Peksos piket \\
\hline $18.00-19.30$ & Sholat & Peksos piket \\
$19.30-20.00$ & Makan malam & Petugas piket \\
\hline $20.00-04.30$ & Istirahat & Pengasuh
\end{tabular}

\section{SABTU}

\begin{tabular}{c|c|c}
\hline JAM & KEGIATAN & PETUGAS \\
\hline $04.30-05.00$ & Bangun pagi dan Sholat & Petugas piket \\
\hline $05.00-07.00$ & Bersih diri \& lingkungan & Petugas piket \\
\hline $07.00-07.30$ & Sarapan pagi & Petugas piket \\
\hline $07.00-08.80$ & Apel & Petugas piket \\
\hline $08.00-12.00$ & Bersih diri \& lingkungan & Pengasuh \\
\hline $12.00-14.00$ & Istirahat, sholat, makan & Peksos piket \\
\hline $14.00-15.30$ & Konseling Psikolog & Psikolog \\
\hline $15.30-16.00$ & Sholat Ashar & Petugas piket \\
\hline $16.00-19.30$ & $\begin{array}{c}\text { Bersih diri \& persiapan } \\
\text { sholat Maghrib }\end{array}$ & Peksos piket \\
\hline $19.30-20.00$ & Makan malam & Petugas piket \\
\hline $20.00-04.30$ & Istirahat & Pengasuh
\end{tabular}

\section{MINGGU}

\begin{tabular}{c|c|c}
\hline JAM & KEGIATAN & PETUGAS \\
\hline $04.30-05.00$ & Bangun pagi dan Sholat & Petugas piket \\
\hline $05.00-07.00$ & Bersih diri \& lingkungan & Petugas piket \\
\hline $07.00-07.30$ & Sarapan pagi & Petugas piket \\
\hline $07.00-09.00$ & Terapi Fisik & Pendamping Fisik \\
\hline $09.00-11.00$ & Istirahat & Peksos \\
\hline $11.00-12.00$ & Konseling Psikolog & Psikolog \\
\hline $12.00-15.30$ & Istirahat,sholat makan & Petugas piket \\
\hline $15.30-16.00$ & Sholat Ashar & Petugas piket \\
\hline $16.00-18.00$ & Istirahat & Pengasuh \\
\hline $18.00-19.30$ & Sholat & Peksos piket \\
\hline $19.30-20.00$ & Makan malam & Peksos piket \\
\hline $20.00-04.30$ & Istirahat & Pengasuh
\end{tabular}

Sumber: Balai Rehabilitasi Sosial Anak Memerlukan Perlindungan Khusus Alyatama Jambi 
Berdasarkan tabel tersebut di atas, kegiatan yang diberikan oleh Balai Rehabilitasi Sosial Anak Memerlukan Perlindungan Khsusus Alyatama Jambi, selain untuk memenuhi kebutuhan baik sandang, pangan, papan dari Anak pelaku tindak pidana, juga diberikan beberapa terapi-terapi serta pembelajaran kepada anak pelaku tindak pidana demi pemulihan mental dan psikis dari anak pelaku tindak pidana, hanya saja dari tabel tersebut terlihat jelas tidak ada bentuk pelatihan kerja yang diberikan kepada anak pelaku tindak pidana, walupun putusan Hakim Pengadilan Negeri Kelas I A Jambi menjatuhkan putusan pelatihan kerja kepada anak pelaku tindak pidana yang di tempatkan di Balai Rehabilitasi Sosial Anak Memerlukan Perlindungan Khusus Alyatama Jambi.

Berbeda dengan Balai Rehabilitasi Anak Memerlukan Perlindungan Khusus Alyatama Jambi yang memang benar-benar tidak memberikan pelatihan kerja terhadap anak pelaku tindak pidana Alyatama Jambi, Pada putusan di Pengadilan Negeri Kupang terdapat 5 anak pelaku tindak pidana yang dijatuhi pidana pelatihan kerja dan semunya merupakan pidana komulatif berupa pidana penjara dan denda, pidana denda diganti dengan pelatihan kerja. Hasil penelitian menunjukan bahwa setelah anak menjalani pidana badan, maka anak tersebut langsung diserahkan ke BAPAS untuk menjalani pelatihan kerja. Adapun terdapat 2 jenis pelatihan kerja yang dapat diberikan di BAPAS kepada anak yaitu 1) Pelatihan mencuci motor dan mobil; dan 2) Pelatihan membersihkan halaman ${ }^{7}$.Walaupun belum ada aturan yang jelas mengenai bagaimana bentuk pidana pelatihan kerja tetapi eksekusi pidana pelatihan kerja yang di lakukan oleh BAPAS pada Pengadilan Negeri Kupang benarbenar telah melaksanakan pelatihan kerja.

Dengan demikian jenis pelatihan kerja yang diberikan terhadap anak sangat minim atau sedikit karena di BAPAS Kupang hanya terdapat 2 jenis pelatihan dengan keterbatasan sarana pendukung pelatihan kerja. Keterbatasan jenis pelatihan yang tersedia di BAPAS Kupang jika dilihat dari kualifikasi pelatihan kerja, maka hanya pelatihan mencuci motor dan mobil yang dapat dikategorikan sebagai bagian dari pelatihan kerja yang sesungguhnya karena mencuci mobil dan motor bagian dari dunia usaha melalui pelatihan mencuci mobil dan motor dapat meningkatkan kemampuan kerja anak tersebut. Dengan memiliki keterampilan mencuci motor dan mobil, maka kelak setelah menjalani masa hukumannya dapat berusaha atau bekerja menggunakan keterampilan mencuci motor dan mobil. Selain itu, dengan keterampilan tersebut, jika anak memiliki modal usaha, maka dapat digunakan untuk membuka usaha cuci motor atau mobil. Sedangkan pelatihan kerja membersihkan halaman, bukan merupakan bagian dari upaya untuk meningkatkan kemampuan anak dalam bekerja, karena perihal kegiatan membersihkan tidak termasuk dalam upaya meningkatkan kemampuan kerja dan tidak membutuhkan pelatihan kerja ${ }^{8}$.

Berdasarkan hal tersebut dapat menjadi suatu perbandingan bahwa di daerah lain dalam melaksanakan pidana pelatihan kerja mereka menerapkan aturanya sendiri untuk melaksanakan hal tersebut, sementara itu di Balai Rehabilitasi Sosial Anak Memerlukan Perlindungan Khusus Alyatama Jambi tetap berpedoman kepada

7 Kadek Widiantri, "Perlindungan Hukum Terhadap Anak Yang Berkonflik Dengan Hukum Yang Dijatuhi Pidana Pelatihan Kerja”, Masalah-Masalah Hukum ,46, 4 (2017), hlm.305.

8 Kadek Widiantri, "Perlindungan Hukum", hlm. 305. 
Peraturan Menteri Sosial Republik Indonesia Nomor 26 Tahun 2018 Tentang Rehabilitasi Sosial dan Reintegrasi Sosial Bagi Anak Yang Berhadapan Dengan Hukum.

2. Kendala yang dihadapi dalam proses Pelaksanaan Pidana Pelatihan Kerja terhadap Anak pelaku tindak pidana di Balai Rehabilitasi Sosial Anak Memerlukan Perlindungan Khusus Alyatama Jambi

Balai Rehabilitasi Sosial Anak Memerlukan Perlindungan Khusus Alyatama Jambi, selaku lembaga yang di pilih oleh Hakim Pengadilan Negeri Kelas I A Jambi dalam menjatuhi putusan pidana pelatihan kerja terhadap anak pelaku tindak pidana, tentunya dalam proses pelaksanaan pemberian pelatihan kerja kepada anak pelaku tindak pidana pasti memiliki beberapa kendala, hal ini tak terlepas belum adanya pedoman mengenai bentuk pelatihan kerja seperti apa yang akan diberikan kepada anak pelaku tindak pidana yang di jatuhi pidana pelatihan kerja, ketiadaan Peraturan Pemerintah mengenai Pelaksanaan Pidana Pelatihan Kerja dari Undang-Undang Nomor 11 Tahun 2012 Tentang Sistem Peradilan Pidana Anak membuat Balai Rehabilitasi Sosial Anak Memerlukan Perlindungan Khusus hanya berpedoman kepada Peraturan Menteri Sosial Republik Indonesia Nomor 26 Tahun 2018 Tentang Rehabilitasi Sosial dan Reintegrasi Sosial Bagi Anak Yang Berhadapan Dengan Hukum. Adapun Kendala yang dihadapi Balai Rehabilitasi Sosial Anak Memerlukan Perlindungan Khusus Alyatama Jambi dalam pelaksanaan pelatihan kerja adalah sebagai berikut:

1. Kendala dari Peraturan

Salah satu bentuk rehabilitasi yang di berikan Balai Rehabilitasi Sosial Anak Memerlukan Perlindungan Khusus Alyatama selaku salah satu lembaga yang menjalani Rehabilitasi Sosial dan Reintegrasi Sosial Bagi Anak Yang Berhadapan Dengan Hukum, terdapat salah satu rehabilitasi dengan memberikan kegiatan pendidikan atau pelatihan vokasional, yaitu pelatihan untuk penyaluran minat dan bakat, serat untuk menyiapkan kemandirian $\mathrm{ABH}$, dalam bentuk keterampilan kerja atau magang kerja. Hanya saja hal ini tak dapat dilakukan oleh Balai Rehabilitasi Sosial Anak Memerlukan Perlindungan Khusus Alyatama Jambi dikarenaka ketiadaan pedoman mengenai seperti apa bentuk pelatihan kerja yang harus diberikan kepada anak pelaku tindak pidana. Sebagaimana disampaikan oleh Nurhasanah Seprianita Selaku Kasi Layanan Rehabilitasi Sosial Anak Memerlukan Perlindungan Khusus Alyatama Jambi menjelaskan:Berdasarkan Peraturan Menteri Sosial Republik Indonesia Nomor 26 Tahun 2018 Tentang Rehabilitasi Sosial dan Reintegrasi Sosial Bagi Anak Yang Berhadapan Dengan Hukum, memang sudah di atur bagi lembaga yang menjadi tempat pelaksanaan rehabilitasi sosial bagi Anak Yang berhadapan Dengan Hukum, salah satu bentuk rehabilitasinya adalah kegiatan vokasional, hanya saja belum adanya aturan yang jelas mengenai bentuk pelatihan kerja yang akan diberikan, oleh sebab itu di Balai Rehabilitasi Sosial Anak Memerlukan Perlindungan Khusus Alyatama Jambi belum menjalankan kegiatan vokasional tersebut ${ }^{9}$.

9 Wawancara dengan Nurhasana Seprianita, Kasi Layanan Rehabilitasi Sosial Anak Memerlukan Perlindungan Khusus Alyatama Jambi, Tanggal 21 Agustus 2019. 
2. Kendala dari Sarana dan Prasarana

Selain faktorperaturan pemerintah mengenai pelaksanaan pelatihan kerja yang belum ada, keterbatasan sarana dan prasarana penunjang untuk melaksanakan pelatihan kerja juga menjadi kendala.

Hal ini juga disampaikan oleh Nurhasanah Seprianita Selaku Kasi Layanan Rehabilitasi Sosial Anak Memerlukan Perlindungan Khusus Alyatama Jambi menjelaskanFaktor lain yang menyebabkan Balai Rehabilitasi Sosial Anak Memerlukan Perlindungan Khusus Alyatama Jambi belum memberikan pelatihan Vokasional adalah belum ketersedian sarana dan prasarana penunjang untuk memberikan pelatihan kerja kepada anak yang menjalankan putusan pelatihan kerja, kemudian belum adanya petugas khusus yang ada untuk memberikan pelatihan kerja tersebut ${ }^{10}$.

3. Kendala dari Pekerja Sosial

Pekerja Sosial yang ada saat ini di Balai Rehabilitasi Sosial Anak Memerlukan Perlindungan Khusus Alyatama Jambi rata-rata hanya memberikan terapi-terapi baik psikososial maupun terapi mental, mereka juga tidak dijadwalkan memberikan pelatihan vokasional karena secara khusus juga bukan merupakan tugas mereka, Karena belum adanya Pekerja Sosial khusus yang bertugas memberikan pelatihan vokasional.

Sebagaimana disampaikan oleh Rita Hayati Selaku Pekerja Sosial Rehabilitasi Sosial Anak Memerlukan Perlindungan Khusus Alyatama Jambi menjelaskandalam memberikan Rehabilitasi di Balai Rehabilitasi Sosial Anak Memerlukan Perlindungan Khusus Alyatama Jambi, yang diberikan adalah rehabilitasi dalam bentuk terapi-terapi baik Psikososial, Mental, serta Spiritual, hal ini bertujuan untuk memulihkan kembali Psikis anak-anak yang berhadapan dengan hukum mengingat anak adalah generasi penerus bangsa yang harus di pikirkan masa depannya ${ }^{11}$.Berdasarkan hal tersebut maka sudah jelas beberapa kendala yang di hadapi Balai Rehabilitasi Sosial Anak Memerlukan Perlindungan Khusus Alyatma jambi dalam memberikan pelatihan Kerja terhadap anak pelaku tindak pidana, selain belum adanya Peraturan Pemerintah mengenai pelaksanaan pidana pelatihan kerja, sarana dan prasarana penunjang untuk melaksanakan pelatihan kerja juga belum tersedia di Balai Rehabilitasi Sosial Anak Memerlukan Perlindungan Khusus Alyatama Jambi, selain itu ketidaksedian pekerja sosial khusus untuk memberikan pelatihan kerja juga menjadi kendala, maka dari itu Balai Rehabilitasi Sosial Anak Memerlukan Perlindungan Khusus Alyatama hanya memberikan terapi-terapi yang berguna untuk pemulihan psikis serta mental dan spiritual dari pada anak pelaku tindak pidana yang ditempatkan di Balai Rehabilitasi Sosial Anak Memerlukan Perlindungan Khusus Alyatama Jambi.Berdasarakan data yang ada mengenai pelaksanaan pidana pelatihan kerja di Balai Rehabilitasi Sosial Anak Memerlukan Perlindungan Khusus Alyatama Jambi, mulai dari bagaimana proses pelaksanaan yang diberikan disana hingga kendala yang dihadapi oleh Balai Rehabilitasi Sosial Anak

10 Wawancara dengan Nurhasana Seprianita, Kasi Layanan Rehabilitasi Sosial Anak Memerlukan Perlindungan Khusus Alyatama Jambi, Tanggal 21 Agustus 2019.

11 Wawancara dengan Rita Hayati, Pekerja Sosial Rehabilitasi Sosial Anak Memerlukan Perlindungan Khusus Alyatama Jambi, Tanggal 21 Agustus 2019. 
Memerlukan Perlindungan Khusus Alyata Jambi, menurut penulis Pidana pelatihan kerja yang memang sudah jelas di cantumkan sebagai pidana pokok yang dapat dijatuhi kepada anak pelaku tindak sebenarnya bertujuan sangat baik guna memepersiapkan anak pelaku tindak pidana dapat berkembang lebih baik dengan memiliki keahlian yang di dapat setelah anak tersebut selesai menjalankan pidana pelatihan kerja tersebut, hanya saja dengan tidak adanya aturan yang mengatur mengenai bentuk pelatihan kerja tersebut menjadi suatu hambatan ketika pidana pelatihan kerja tersebut akan di laksanakan, jika di bandingkan dengan daerah lain yang telah yang memang benar-benar melaksanakan pidana pelatihan kerja dengan memberikan pelatihan pekerjaan kepada anak pelaku tindak pidana berupa mencuci mobil, seutuhnya Balai Rehabilitasi Sosial Anak Memerlukan Perlindungan Khusus Alyatama Jambi juga dapat menerapkan pidana pelatihan kerja melalui pendidikan atau pelatihan vokasional sesuai minat serta bakat anak, dengan memeberikan hal ini juga dapat memberikan bekal keahlian kepada anak pelaku tindak pidana guna mempersiapkan diri setelah ia selesai menjalankan pidana pelatihan kerja di Balai Rehabilitasi Sosial Anak Memerlukan Perlindungan Khusus Alyatama Jambi, sebaiknya Balai Rehabilitasi Sosial Anak Memerlukan Perlindungan Khusus Alyatama Jambi, sebagai lembaga yang telah di tunjuk di dalam Putusan oleh Hakim Pengadilan Negeri Jambi, mampu menjalankan pelatihan kerja melalui pelatihan vokasional, agar anak-anak pelaku tindak pidana benar-benar mendapatkan keahlian untuk bekal mereka setelah selesai menjalankan pidana pelatihan kerja tersebut, menurut penulis apa yang telah diberikan oleh Balai Rehabilitasi Sosial Anak Memerlukan Perlindungan Khusus Alyatama Jambi kepada anak-anak pelaku tindak pidana berupa terapi-terapi sangat lah baik dan tidak menyalahi aturan dari pada tugas Balai tersebut,hanya saja perlu di berikan berupupa pelatihan kerja melalui pendidik vokasional sesuai minat dan bakt dari pada anak-anak tersebut seperti yang telah di jelaskan di dalam Pasal 31 Peraturan Menteri Sosial Republik Indonesia Nomor 26 Tahun 2018 Tentang Rehabilitasi Sosial dan Reintegrasi Sosial Bagi Anak Yang Berhadapan Dengan Hukum.

\section{SIMPULAN}

Berdasarkan pembahasan yang diuraikan oleh penulis maka dapat disimpulkan sebagai berikut: Pelaksanaan pidana pelatihan kerja terhadap anak pelaku tindak pidana di Balai Rehabilitasi Sosial Anak Memerlukan Perlindungan Khusus Alyatama Jambi dapat dikatakan belum terlaksana, walaupun di dalam Putusan Hakim Pengadilan Negeri Kelas I A Jambi menjatuhi Putusan Pelatihan Kerja terhadap anak pelaku tindak pidana, namun Balai Rehabilitasi Sosial Anak Memerlukan Perlindungan Khusus Alyatama Jambi sebagai tempat pelaksanaan pelatihan kerja tersebut belum memberikan pelatihan kerja terhadap anak pelaku tindak pidana hal tersebut dikarenakan belum adanya Peraturan Pemerintah mengenai pelaksanaan pidana pelatihan kerja, sehingga Balai Rehabilitasi Sosial Anak Memerlukan Perlindungan Khusus Alyatama Jambi, selain menjamin kebutuhan dasar seperti sandang, pangan, serta tempat tinggal kepada anak pelaku tindak pidana, juga memberikan Rehabilitasi berupa Terapi-terapi mulai dari terapi Psikososial hingga terapi mental dan spiritual, sesuai yang di atur di dalam Pasal 27 Peraturan Menteri Sosial Republik Indonesia 
Nomor 26 Tahun 2018 Tentang Rehabilitasi Sosial dan Reintegrasi Sosial Bagi Anak Yang Berhadapan Dengan Hukum. Terapi-terapi tersebut diberikan bertujuan untuk mengembalikan keadaan psikis maupun mental dan spiritual anak pelaku tindak pidana menjadi lebih baik lagi. Sedangkan kendala yang dihadapi Balai Rehabilitasi Sosial Anak Memerlukan Perlindungan Khusus Alyatama Jambi dalam memberikan Pelaksanaan Pelatihan Kerja kepada anak pelaku tindak pidana terdapat beberapa kendala, yang paling utama adalam belum tersedianya pedoman bagaimana bentuk pelatihan kerja yang harus diberikan, hal ini disebabkan belum tersedianya Peraturan Pemerintah mengenai Pelaksanaan Pelatihan kerja dari Undang-Undang Nomor 11 Tahun 2012 Tentang Sistem Peradilan Pidana Anak, kemudian kendala yang kedua adalah belum tersedianya sarana dan prasarana yang akan menjadi penunjang bagi Balai Rehabilitasi Sosial Anak Memerlukan Perlindungan Khusus Alyatama Jambi untuk memberikan Pelatihan kerja yang sesuai dengan keterampilan anak, selanjutnya yang menjadi kendala terakhir adalah tidak adanya pekerja sosial yang secara khusus akan memberikan pendidikan serta pelatihan kerja terhadap anak pelaku tindak pidana. Kendala ini lah yang menyebabkan hingga saat ini Balai Rehabilitasi Sosial Anak Memerlukan Perlindungan Khusus Alyatama Jambi belum memberikan pelaksanaan pelatihan kerja terhadap anak pelaku tindak pidana yang di tempatkan di Balai Rehabilitasi tersebut.

\section{DAFTAR PUSTAKA}

\section{Dokumen Hukum}

Republik Indonesia. Undang-Undang Nomor 11 Tahun 2012 Tentang Sistem Peradilan Pidana Anak, Lembaran Negara Republik Indonesia Tahun 2012 Nomor 153

\section{Buku}

Djamil, M. Nasir. Anak Bukan Untuk Dihukum. Jakarta: Sinar Grafika, 2013.

Gultom, Maidin.Perlindungan Hukum Terhadap Anak Dalam Sistem Peradilan Pidana Anak Di Indonesia. Bandung: Refika Aditama, 2014.

Lamintang, P.A.F. Hukum Penitensier Indonesia. Jakarta: Sinar Grafika, 2010.

Mulyadi, Lilik. Wajah Sistem Peradilan Pidana Anak Indonesia. Bandung:Alumni, 2014.

Marlina. Hukum Penitensier. Bandung: Refika Aditama, 2011.

Moeljatno. Asas-Asas Hukum Pidana. Jakarta: Rineka Cipta,2008.

Nasution, Bahder Johan. Metode Penelitian Ilmu Hukum. Bandung: CV. Mandar Maju,2008.

Pramukti, Angger Sigit. Sistem Peradilan Pidana Anak. Yogyakarta: Pustaka Yustisia,2015.

Sambas, Nanang.Peradilan Pidana Anak. Bandung: Graha Ilmu, 2013.

Supeno, Hadi.Kriminalisasi Anak. Jakarta: Gramedia Pustaka Utama, 2010. 
Setiady, Tolib.Pokok-Pokok Hukum Penitensier Indonesia, Bandung: Alfabeta,2010.

Umar, Dzulkiflidan Jimmy. Kamus Hukum. Surabaya: Grahamedia Press, 2012.

Wiyono, R.Sistem Peradilan Pidana Anak Di Indonesia. Jakarta: Sinar Grafika,2016.

Waluyo, Bambang. Pidana dan Pemidanaan. Jakarta: Sinar Grafika, 2004.

\section{Jurnal/ Majalah Ilmiah}

Hafrida, YuliaMonita, dan EliZabeth Siregar. "Pembinaan Narapidana Anak Di Lembaga Pemasyarakatan Anak Sel Bulu Muaro Bulian.”Publikasi Pendidikan, 3 (2015).

Kadek Widiantari.“Perlindungan Hukum Terhadap Anak Yang Berkonflik Dengan Hukum Yang Dijatuhi Pidana Pelatihan Kerja”. Masalah-Masalah Hukum 46, 4, (2017). 